\title{
Effect of tonsillectomy on humoral immunity
}

\author{
Nasrin $\mathrm{M}^{1}$, Miah MRA ${ }^{2}$, Datta $\mathrm{PG}^{3}$, Saleh AA ${ }^{2}$, Anwar $\mathrm{S}^{2}$, Saha $\mathrm{KL}^{3}$ \\ ${ }^{1}$ Department of Microbiology, Bangladesh Medical College, ${ }^{2}$ Department of Microbiology \\ and Immunology, Bangabandhu Sheikh Mujib Medical University (BSMMU), Dhaka, \\ ${ }^{3}$ Department of Otolaryngology, BSMMU, Dhaka, Email: doctormahfuza@yahoo.com
}

\begin{abstract}
Tonsils are one of the important secondary lymphoid organ in immune system. It remains controversial whether tonsillectomy results in decreased serum immunoglobulin level. The purpose of this study was to observe the effect of tonsillectomy on humoral immunity parameters among the patients with tonsillar disease. Total group A 70 patients up to the age of 18 years, who were enrolled for tonsillectomy and 30 age matched children group B were included for comparative study. Serum IgG, $\operatorname{IgM}$ and IgA levels were measured in all 70 patients before tonsillectomy and in 56 patients who came for $1^{\text {st }}$ follow-up after one month and 30 patients who came for 2 nd follow up after three months of tonsillectomy. Serum $\operatorname{IgG}, \operatorname{IgM}$ and $\operatorname{IgA}$ levels were also measured in group B children. Serum $\operatorname{IgG}$, IgM and $\operatorname{IgA}$ levels in patients of group A did not show any significant difference in comparison to group B. One month after tonsillectomy the level of IgG was slightly decreased and IgM and IgA were increased compared to preoperative value but not statistically significant. All IgG, IgM and IgA were also not significantly altered in comparison to group B. Three months after tonsillectomy serum $\mathrm{IgG}$, IgM and IgA level were found decreased in comparison to pre operative value and group B, among which difference of only IgG was significant. After tonsillectomy humoral parameters were found reduced but overall impact on humoral immune status was not significantly altered.
\end{abstract}

\section{Introduction}

Palatine tonsils are one of the mucosa-associated lymphoid tissues (MALT), located at the entrance of the upper respiratory and gastrointestinal tract. This significant position implies a key role of the palatine tonsils in initiating immune responses against various antigens that enter the body through mouth and nose ${ }^{1}$. Tonsils contain both $\mathrm{B}$ and $\mathrm{T}$ lymphocytes but B cells predominant, implying that both cell mediated and humoral function are performed by tonsils ${ }^{2}$. Tonsillar plasma cells produce all five immunoglobulin classes but predominantly $\operatorname{IgG}$ and $\operatorname{IgA}^{3}$. Since the humoral role of the immune function of the tonsil is its most important one, the immunological function of the tonsil can be assessed by serum immuno-globulin estimations in patients with chronic tonsillitis and in their follow-up after tonsillectomy ${ }^{4}$.

In children, tonsillar disease is one of the common cause of primary care visit to physicians and the choice of treatment is often tonsillectomy. Although tonsillectomy is a common surgical procedure, its possible immunological sequel has not been fully investigated. The growing understanding in recent years of the immunological functions of tonsil has led to arguments against tonsillectomy. Majority of the children in our country are living below the poverty level. It is assume that they have naturally lowered immunity both cellular and humoral. As tonsil is an important secondary lymphoid organ, tonsillectomy may further reduce the immune status. In overseas, several studies have been done about the effect of tonsillectomy on immune system. But no such study has been conducted in our country.

This study was undertaken to see the effect of tonsillectomy on serum immunoglobulins level among the children with tonsillar disease.

\section{Material and Methods}

It was an observational study. Total 70 patients upto the age of 18 years, who were enrolled for tonsillectomy (group A) because of chronic tonsillitis and adenotonsillar hypertrophy at three different hospitals in Dhaka city during October 2010 to September, 2011 were included in this study. Thirty age matched children were selected without any history of tonsillectomy (group B), chronic tonsillitis and adenotonsillar hypertrophy. Children with known case of immunodeficiency disorder or any autoimmune disease and having viral and other infection for last 3 months were excluded from the study. Some patients were dropped out from the study in subsequent follow up period. Out of 70 patients, 56 patients came for $1^{\text {st }}$ follow-up after one month of tonsillectomy, of which 30 patients came for $2^{\text {nd }}$ follow up after three months of tonsillectomy. Serum of all 70 patients 
before tonsillectomy, 56 patients of 1st follow up, 30 patients of 2 nd follow up after tonsillectomy and 30 children in group B were tested for $\operatorname{IgG}, \operatorname{IgM}$ and $\operatorname{IgA}$.

Final comparative study done between 30 patients attended two follows of Group-A and 30 patients of Group-B without tonsillectomy.

Student's t test for unpaired data was used to compare the results between patients and group B. The comparison of pre and post operative values were performed by paired t test, $\mathrm{P}$ values $<0.05$ were regarded as significant.

\section{Results}

Among group A 70 patients before tonsillectomy mean IgG, IgM and IgA levels were 14.31, 1.37 \& $1.66 \mathrm{~g} / \mathrm{l}$ respectively. In 1 st follow of 56 patients one month after tonsillectomy these immunoglobulin levels were $13.83,1.47 \& 1.54 \mathrm{~g} / \mathrm{l}$ respectively; and in 2 nd follow up of 30 patients after three months tonsillectomy these values were 11.56, 1.31, and $1.47 \mathrm{~g} / \mathrm{l}$ respectively. Among group B children these values were $13.97,1.56 \&$ 1.73 respectively (Table-I).

IgG, IgM and IgA level among group B and 30 patients who were available before tonsillectomy, one month and three months after tonsillectomy are shown in table II. Before tonsillectomy serum IgG level was slightly higher where $\operatorname{IgM}$, IgA levels were slightly lower compared to group $\mathrm{B}$; one month after tonsillectomy the level of $\mathrm{IgG}$ was slightly decreased and $\operatorname{IgM}$ and $\operatorname{IgA}$ were increased compared to preoperative value but not statistically significant. All IgG, IgM and IgA were also not significantly altered in comparison to group B. Three months after tonsillectomy IgG level dropped significantly $(\mathrm{P}<0.01)$ where $\operatorname{IgM}$ and IgA did not show any significant difference compared to preoperative and group B.

Table I: Serum IgG, IgM and IgA level in patient group A before tonsillectomy, one month and three months after tonsillectomy and in group B

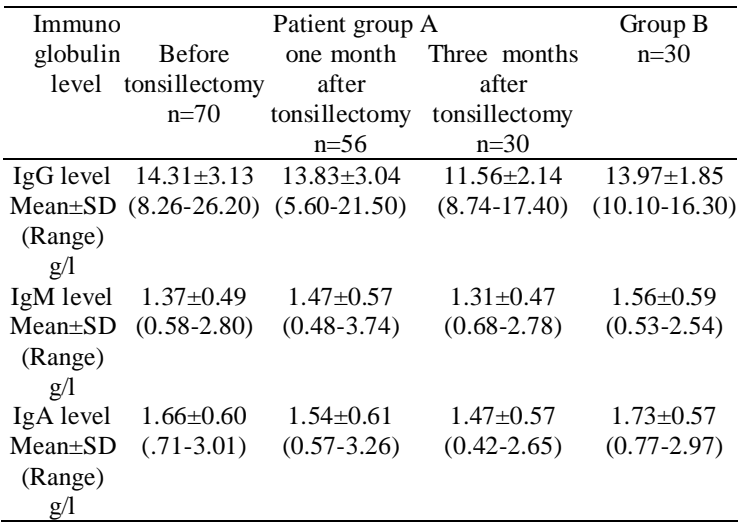

Table II: Serum IgG, IgA, IgM level in 30 patients group A before tonsillectomy, one month and three months after tonsillectomy and 30 group B

\begin{tabular}{|c|c|c|c|c|}
\hline \multirow{2}{*}{$\begin{array}{c}\text { Immunoglob } \\
\text { ulin level }\end{array}$} & \multicolumn{3}{|c|}{30 , Patient group of $\mathrm{A}$} & \multirow{2}{*}{ Group B } \\
\hline & $\begin{array}{c}\text { Before } \\
\text { tonsille- } \\
\text { ctomy }\end{array}$ & $\begin{array}{c}\text { One month } \\
\text { after } \\
\text { tonsillectomy }\end{array}$ & $\begin{array}{l}\text { Three } \\
\text { months after } \\
\text { tonsillectomy }\end{array}$ & \\
\hline IgG level & $14.76 \pm 3.96$ & $14.04 \pm 2.96$ & $11.56 \pm 2.14$ & $13.97 \pm 1.85$ \\
\hline $\begin{array}{l}\text { Mean } \pm S D \\
\text { (Range) g/l }\end{array}$ & $(8.26-26.20)$ & $(8.19-21.50)$ & $(8.74-17.40)$ & $(10.10-16.30)$ \\
\hline $\begin{array}{l}\text { IgM level } \\
\text { Mean } \pm \text { SD } \\
\text { (Range) g/l }\end{array}$ & $\begin{array}{c}1.35 \pm 0.55 \\
(0.78-2.80)\end{array}$ & $\begin{array}{c}1.50 \pm 0.65 \\
(0.53-3.74)\end{array}$ & $\begin{array}{c}1.31 \pm 0.47 \\
(0.68-2.78)\end{array}$ & $\begin{array}{c}1.56 \pm 0.59 \\
(0.53-2.54)\end{array}$ \\
\hline $\begin{array}{l}\text { IgA level } \\
\text { Mean } \pm \text { SD } \\
\text { (Range) g/l }\end{array}$ & $\begin{array}{c}1.59 \pm 0.54 \\
(0.71-2.91)\end{array}$ & $\begin{array}{c}1.62 \pm 0.61 \\
(0.57-2.70)\end{array}$ & $\begin{array}{c}1.47 \pm 0.57 \\
(0.42-2.65)\end{array}$ & $\begin{array}{c}1.73 \pm 0.57 \\
(0.77-2.97)\end{array}$ \\
\hline
\end{tabular}

\section{Discussion}

The tonsils and adenoid are parts of the Waldeyer ring and are important elements in the defense against airborne and alimentary organisms. The function of the palatine tonsil is to process the environmental antigen and participate with the initiation and maintenance of the local and systemic immunity. Tonsillectomy has long been one of the most frequently performed surgical procedures in children. The question of whether removal of tonsils and adenoids compromises the protection of the upper respiratory tract resulting in immunodeficiency continues to be the subject of debate 5 .

In the present study, among group A 70 patients before tonsillectomy serum IgG level was slight higher while $\operatorname{IgM}$, IgA levels were slight lower compared to group B. Similar findings were observed by Baradaranfar et al (2007) ${ }^{6}$ in Iran who reported slightly higher level of IgG and slightly lower level of $\operatorname{IgM}$ in patient group compared to control group. But another study ${ }^{7}$ has shown higher serum of $\operatorname{IgA}, \operatorname{IgG}$ and IgM level in patients before operation than that of the control group. Sainz et al. (1992) ${ }^{\mathbf{8}}$ in Spain and Lal et al (1984) ${ }^{\mathbf{9}}$ in India also reported increased level of $\mathrm{IgG}, \mathrm{IgM}$ and IgA in patients with chronic tonsillitis than that of control group. In the present study before tonsillectomy among the patients with tonsillar disease, serum IgG level was slight higher while IgM, IgA levels were slight lower compared to group $\mathrm{B}$. The reason for this difference might be that the course of disease in patients was more chronic. IgM antibodies are produced during the acute phase of infectious diseases and their serum levels decrease 1-3 months after infection but IgG antibodies represent in the chronic infections and their levels are also increased in recurrent infections ${ }^{\mathbf{1 0}}$.

Among 30 patients, who were available before tonsillectomy and also $1^{\text {st }}$ and $2^{\text {nd }}$ follow up, before 
tonsillectomy mean value of IgG was slight higher where $\operatorname{IgM}$ and IgA levels were slight lower compared to group B. One month after tonsillectomy serum IgG level was decreased, while $\operatorname{IgM}$ and $\operatorname{IgA}$ levels were slightly increased compared to preoperative value but not significant. Three months after tonsillectomy mean IgG level was significantly $(\mathrm{P}<0.01)$ lower than group $\mathrm{B}$ and preoperative value, though the value was within the range of group B. On the other hand, serum $\operatorname{IgM}$ and $\operatorname{IgA}$ level although lower than group B and preoperative value but did not show any significant difference. Baradaranfar et al (2007) ${ }^{6}$ showed, significantly decreased IgG level 6 months after operation but serum IgM level did not differ significantly compared to control group. Ashmawy et al (1980) ${ }^{4}$ in Egypt reported that among patient with chronic tonsillitis, before tonsillectomy the level of $\operatorname{IgG}$ and $\operatorname{IgA}$ in serum were significantly increased compared to control group, while the IgM level were not changed significantly and two months after tonsillectomy, these increased level of IgG and IgA were significantly reduced than preoperative value but postoperative level value did not differ significantly with control group.

Lal et al (1984) ${ }^{9}$ in India showed that the mean preoperative level of serum $\operatorname{IgG}$ and $\operatorname{IgA}$ were significantly higher in patients with chronic tonsillitis than in the control group; the values dropped 1 month after tonsillectomy, the postoperative values being comparable with those of the control group. In two study of Turkey, done by Ikinciogullar1 et al (2002) ${ }^{\mathbf{5}}$ and Kaygusuz et al $(2003)^{11}$, the levels of $\operatorname{IgG}, \operatorname{IgM}$ and $\operatorname{IgA}$ were increased before operation and decreased one month after operation. From the above mentioned studies, it is observed that the level of immunoglobulins were increased before operation and decreased after operation due to removal of infected tissue $\&$ continuous antigenic stimulation.

In this study the decreased level of $\mathrm{IgG}$, three months after tonsillectomy might be due to removal of the tonsils which contribute to the production of immunoglobulins. As the serum concentration of $\mathrm{IgG}$ is several times greater than that of $\operatorname{IgA}$ or IgM, removal of the tonsils will lead to a significant decrease in its level, while the levels of IgA and IgM are not significantly reduced ${ }^{\mathbf{1 0}}$.

Conclusion: IgG level was found significantly decreased after three months of tonsillectomy though the value was within the range of group B. After tonsillectomy humoral parameters were found reduced but overall impact on immune status was not significantly altered. Long term follow up is recommended to see any change of immune status after tonsillectomy.

\section{Acknowledgement}

The authors express their gratitude to the Ministry of Science and Information \& Communication Technology, Govt. of People's Republic of Bangladesh for financing the study.

\section{References}

1. Bernstein JM, Gorfien $\mathrm{J}$ and Brandtzaeg $\mathrm{P}$. The immunobiology of the tonsils and adenoids. Ogra Mucosal immunology. Academic Press, San Diego. 1999:1339-1362.

2. Mckerrow WS. Disease of tonsil. In: Gleeson M, Browning GG, Burton MJ, Clarke R (eds): ScottBrown' Otolaryngology, Head and Neck Surgery1 (B): Seventh edition. London: Hodder Education; 2008: 1219-1220.

3. Sebastia LIA, Ramirez MJF, Molla CL, Llatas C, Mocholi P, Ruiz MD, Ferriol JE and Martinez RL. Changes in immunoglobulin levels following adenoidectomy and tonsillectomy. Acta Otolaryngol 2004 ;55: 404-408.

4. Ashmawy ES, Taha A, Fatt-hi A, Basyouni A and Zaher S. Serum immunoglobulins in patients with chronic tonsillitis.J Laryngol Otol 1980; 94:1037-1045.

5. Ikinciogullari A, Dogu F, Ikinciogullari A, Egin Y and Babacan E. Is immune system influenced by adenotonsillectomy in children? Int $\mathrm{J}$ Pediatr Otorhinolaryngol $2002 ; 66: 251-257$.

6. Baradaranfar MH, Dodangeh F, Zahir ST and Atar M. Humoral and cellular immunity parameters in children before and after adenotonsillectomy. Acta Medica Iranica 2007; 45(5): 345-350.

7. Jurkiewicz ZB and Jurkiewicz D. Implication of immunological abnormalities after adenotonsillotomy. Int J Pediatr Otorhinolaryngol 2002; 64:127-132.

8. Sainz M, Gutierrez F, Moreno PM, Muñoz C and Ciges M. Changes in immunologic response in tonsillectomized children. Immunosuppression in recurrent tonsillitis. Clin Otolaryngol Allied Sci 1992; 17 (5): 376-379.

9. Lal H, Sachdeva OP and Mehta HR. Serum immunoglobulins in patients with chronic tonsillitis. J. Laryngol. Otol 1984; 98: 1213-1216.

10. Jefferis R. Antibodies. In: Immunology, Seventh edition, Male D. Brostoff J, Roth DB, Roitt I (ed) Mosby, Philadelphia. 2006: 65-67.

11. Kaygusuz I, Godekmerdan A, Karlidag T, Keles E, Yalcin S and Aral I. Early stage impacts of tonsillectomy on immune functions of children. Int $\mathbf{J}$ Pediatr Otorhinolaryngol 2003; 67: 1311-131. 